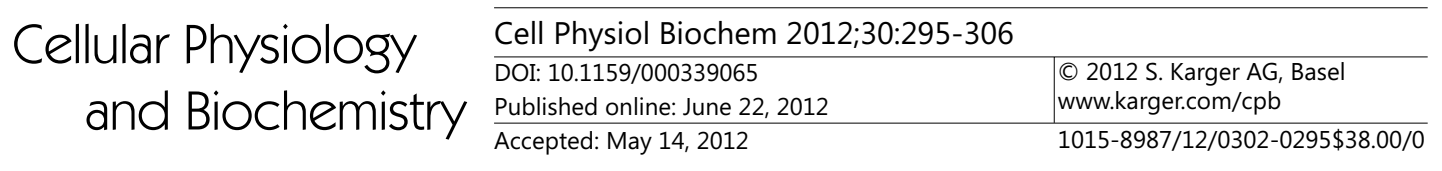

\title{
Downregulation of Fetuin-B and Zinc- $\alpha 2-$ glycoprotein is Linked to Impaired Fatty Acid Metabolism in Liver Cells
}

\author{
Jung-Won Choi Hao Liu Rajib Mukherjee Jong Won Yun \\ Department of Biotechnology, Daegu University, Kyungsan, Kyungbuk
}

\section{Key Words}

Plasma proteome - High fat diet - Obesity-prone and -resistant rats - Fetuin-B - Zinc- $\alpha 2$ glycoprotein $\bullet$ RNA interference

\begin{abstract}
Background: Our recent proteomic study has shown that plasma protein levels of fetuin-B (Ft-B) and zinc- $\alpha 2$-glycoprotein (ZAG) are significantly elevated in obesity-resistant (OR) rats exposed to a high fat diet. Time profiling of the plasma concentrations of Ft-B and ZAG in OR rats has shown stable regulation of these proteins throughout the entire period of rat breeding. Methods: To firmly establish roles for these proteins in lipogenesis, we efficiently knocked down (KD) the genes FETUB and AZGP1 encoding Ft-B and ZAG, respectively, using siRNA in Chang liver cells. Results: Reduced expression of FETUB and AZGP1 led to a significant increase in the expression of lipogenic genes, thereby resulting in higher lipid levels in both KD cells. Collectively with our previous findings, we confirmed that Ft-B was similarly regulated with Ft-A, in that their plasma protein levels were commonly reduced in diet-induced obese rats. Conclusion: Our results provide a possible relationship between reduced plasma protein levels of Ft-B and ZAG and higher risk of diet-induced obesity through impaired fatty acid metabolism in hepatocytes.

Copyright (C) 2012 S. Karger AG, Basel
\end{abstract}

\section{Introduction}

One of the main focuses of current obesity research is why some humans become obese easily while others resist development of obesity when exposed to a high-calorie diet. To solve this question, we recently attempted to analyze the proteomes of plasma and metabolic organ tissues in rats exposed to a high fat diet (HFD) [1-4]. One of the exciting results from

Dr. Jong Won Yun and Dr. Jung-Won Choi Department of Biotechnology, Daegu University, Kyungsan, 


\section{Cellular Physiology Cell Physiol Biochem 2012;30:295-306

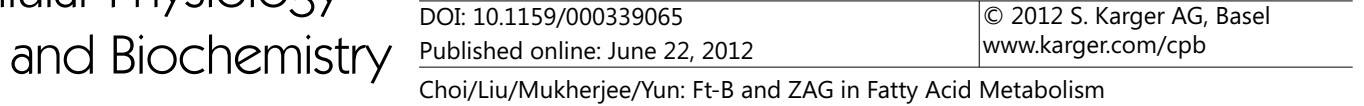

our proteomic studies is that greater regulation of enzymes is involved in $\beta$-oxidation of fats and that downregulation of lipogenic enzymes occurs in the majority of metabolic organs in obesity-resistant rats [2-4].

Moreover, numerous plasma proteins are differentially regulated between obesityprone (OP) and -resistant (OR) rats fed a HFD $[1,5]$. Two of these differentially regulated plasma proteins have attracted our attention. Ft-B has not yet been linked to obesity and ZAG is not associated with lipogenesis in the liver.

To date, there is limited information about Ft-B, even though there are many reports on Ft-A, the first member of the fetuin family [6]. Ft-A and Ft-B both show differences and similarities in gene regulation and possess partly overlapping functions [6, 7]. Ft-A, also known as human $\alpha 2$-Heremans-Schmid glycoprotein (AHSG), is a multifunctional glycoprotein secreted by hepatocytes [8]. Ft-A inhibits insulin-stimulated insulin receptor tyrosine kinase, and Ft-A knockout mice display improved insulin sensitivity and resistance to weight gain in response to a HFD [9]. In addition, serum Ft-A is upregulated in obesity [10] and other diseases [11-14]. However, there are also several contradictory results indicating no association between blood protein levels of Ft-A with insulin sensitivity or resistance [15] or lower levels in patients with type 2 diabetes $[16,17]$.

Ft-B is the second member of the fetuin family [6]. Similarly, it is an inhibitor of calcium phosphate precipitation and is downregulated in Ft-A-deficient mice [7] as well as during the acute phase of inflammation in rats [6]. In our previous studies, we demonstrated for the first time decreased plasma protein levels of both Ft-A and Ft-B in obese rats fed a HFD, suggesting their possible links to obesity $[1,5]$. However, no evidence has been provided to date in relation to the physiological significance of Ft-B in association with obesity until the current study was conducted.

Zinc- $\alpha 2$-glycoprotein (ZAG) is a soluble plasma protein secreted from various tissues such as liver and adipose tissues $[18,19]$. A growing body of evidence indicates that ZAG is involved in the regulation of body weight in both human subjects and rodents [20-25]. We also observed that plasma protein levels of ZAG are significantly reduced in both male and female obese rats fed a HFD [1,5]. Although several studies have demonstrated the physiological role of ZAG $[21,25,26]$, no clear correlation between ZAG expression and lipogenesis has been reported in liver cells.

Therefore, the primary goal of this study was to investigate the physiological significance of Ft-B and ZAG in hepatic lipogenesis. To this end, we individually knocked down FETUB and $A Z G P 1$, after which we examined the transcript and protein levels of lipogenic enzymes (Fig. 1).

\section{Materials and Methods}

\section{Animals and diets}

Five-week-old male SLC Sprague-Dawley (SD) rats were purchased from Daehan Experiment Animals (Seoul, Korea), raised in separate cages for the exclusion of diverse effects among rats, and maintained under a controlled environment $\left(23 \pm 2^{\circ} \mathrm{C} ; 12\right.$ :12-h light-dark cycle) with free access to water and chow. Rats were divided randomly two groups, namely 10 rats fed a normal diet (ND, 12\% calories from fat) and 20 rats fed a HFD ( $45 \%$ calories from fat), after an adaption period of 1 week. The compositions of the ND and HFD are shown in Table 1. After 8 weeks, rats were subdivided into OP and OR groups according to body weight gain. Body weight and food consumption of all rats were monitored weekly for 8 weeks. Animal experiments were approved by the Committee for Laboratory Animal Care and Use of Daegu University, and all procedures were conducted in accordance with the Guide for the Care and Use of Laboratory Animals published by the National Institutes of Health.

\section{Preparation of blood plasma sample}

Blood was rapidly collected from the end of the rat tail under anesthesia by $3 \%$ diethyl ether in EDTAtubes (BD, Franklin Lakes, NJ, USA) at $0,2,4,6$, and 8 weeks after feeding of a ND or HFD. Plasma was isolated from blood by centrifugation $(3,000 \times g, 10 \mathrm{~min})$, frozen in liquid nitrogen, and stored at $-80^{\circ} \mathrm{C}$. 


\begin{tabular}{ll|l} 
Cellular Physiology & Cell Physiol Biochem 2012;30:295-306 \\
\cline { 2 - 2 } $\begin{array}{l}\text { DOI: 10.1159/000339065 } \\
\text { and Biochemistry }\end{array}$ & $\begin{array}{l}\text { Published online: June 22, 2012 S. Karger AG, Basel } \\
\text { www.karger.com/cpb }\end{array}$ \\
\cline { 2 - 3 } & Choi/Liu/Mukheriee/Yun: Ft-B and ZAG in Fatty Acid Metabolism
\end{tabular}

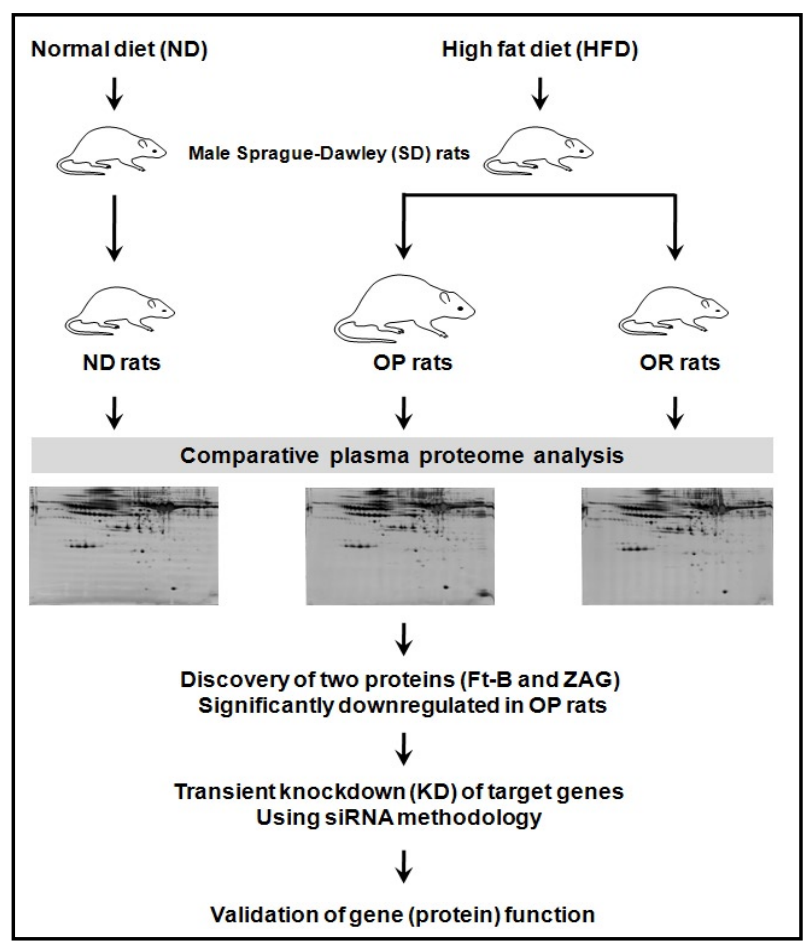

Fig. 1. Experimental design of this study.

Protein concentration of plasma was determined by the Bradford method [27] using protein assay dye reagent concentrate (Bio-Rad, Hercules, CA, USA).

\section{2-DE analysis}

To compare the altered expression levels of plasma proteins with time, 2-DE was carried out three times using mixed plasma from seven rats per group, which consisted of controls fed a ND as well as OP and OR rats fed a HFD, and conducted according to previous methods [28]. Briefly, $18 \mathrm{~cm}$ IPG DryStrips (GE Healthcare, Buckinghamshire, UK; $\mathrm{pH} 4$-7) were rehydrated for $26 \mathrm{~h}$ with $25 \mu \mathrm{g}$ of plasma proteins and solution containing $7 \mathrm{M}$ urea (Bio Basic, Ontario, Canada), 2 M thiourea (Sigma, St. Louis, MO, USA), 4\% CHAPS (Bio Basic), 1 mM PMSF (Sigma), 20 mM DTT (GE Healthcare), and 2\% IPG buffer (Bio-Rad). Immobilized pH gradient (IPG)-isoelectric focusing (IEF) was performed in a PROTEIN IEF cell (Bio-Rad) as follows: $15 \mathrm{~min}$ at $250 \mathrm{~V}, 3 \mathrm{~h}$ at $250-10,000 \mathrm{~V}, 6 \mathrm{~h}$ at $10,000 \mathrm{~V}$, and held at $500 \mathrm{~V}$ until ready to run the second dimension. The gel strips were equilibrated in a solution containing $6 \mathrm{M}$ urea, 2\% SDS (Generay Biotech, Shanghai, China), 1\% DTT, 30\% glycerol (Bio Basic), and $50 \mathrm{mM}$ Tris-HCl (pH 6.8) for 20 min, followed by further incubation in the same solution, except for replacement of DTT with 2.5\% iodoacetamide (Bio-Rad)

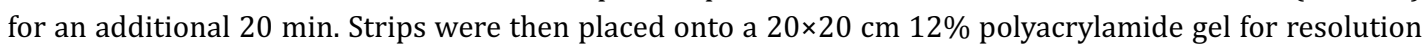
in the second dimension, and fractionation was performed with the Laemmli SDS-discontinuous system at a constant voltage of $15 \mathrm{~mA}$ per gel for $14 \mathrm{~h}$. The gels with separated proteins were visualized by silver staining for image analysis and peptide mass fingerprinting (PMF).

\section{Image analysis}

Gels were imaged on a UMAX PowerLook 1120 (Maxium Technologies, Akron, OH, USA), and images were analyzed using modified ImageMaster 2-D software V4.95 (GE Healthcare). A reference gel was selected from gels of the ND group, and detected spots from the other gels were matched with those in the reference gel. Each spot intensity volume was processed by background subtraction and total spot volume normalization. Relative optical density and relative volume were calculated for comparison of the differences between gels.

\section{Protein identification}

For protein identification, spots were excised, digested with trypsin (Promega, Madison, WI), mixed with $\alpha$-cyano-4-hydroxycinnamic acid in $50 \%$ acetonitrile/ $0.1 \%$ trifluoroacetic acid, and subjected to 


\begin{tabular}{ll|l} 
Cellular Physiology & Cell Physiol Biochem 2012;30:295-306 \\
\cline { 2 - 2 } $\begin{array}{l}\text { DOI: 10.1159/000339065 } \\
\text { and Biochemistry }\end{array}$ & $\begin{array}{l}\text { Published online: June 22, 2012 S. Karger AG, Basel } \\
\text { www.karger.com/cpb }\end{array}$ \\
\cline { 2 - 3 } & Choi/Liu/Mukheriee/Yun: Ft-B and ZAG in Fatty Acid Metabolism
\end{tabular}

\begin{tabular}{|c|c|c|}
\hline Component & ND & HFD \\
\hline \multicolumn{3}{|c|}{ Composition by weight, $\mathrm{g} / \mathrm{kg}$} \\
\hline Casein & 200 & 200 \\
\hline Cornstarch & 150 & 155 \\
\hline Sucrose & 500 & 50 \\
\hline Dextrose & 0 & 132 \\
\hline Cellulose & 50 & 50 \\
\hline Soybean oil & 0 & 25 \\
\hline Corn oil & 50 & 0 \\
\hline Lard & 0 & 175 \\
\hline Mineral mix ${ }^{1)}$ & 35 & 35 \\
\hline Vitamin $\operatorname{mix}^{2)}$ & 10 & 10 \\
\hline $\mathrm{TBHQ}^{3)}$ & 0 & 0.014 \\
\hline DL-Methionin & 3 & 0 \\
\hline L-cystine & 0 & 3 \\
\hline Choline bitartrate & 2 & 2.5 \\
\hline \multicolumn{3}{|c|}{ Composition by calories, $\%$} \\
\hline Protein & 21 & 20 \\
\hline Carbohydrate & 68 & 35 \\
\hline Fat & 12 & 45 \\
\hline Total & $3,902 \mathrm{kcal} / \mathrm{kg}$ & $4,776 \mathrm{kcal} / \mathrm{kg}$ \\
\hline \multicolumn{3}{|c|}{$\begin{array}{l}\text { T) Mineral mix; sucrose }(118.03 \mathrm{~g} / \mathrm{kg}) \text {, calcium phosphate dibasic }(500 \\
\mathrm{g} / \mathrm{kg}) \text {, sodium chloride }(74 \mathrm{~g} / \mathrm{kg}) \text {, potassium citrate }(220 \mathrm{~g} / \mathrm{kg}) \text {, } \\
\text { potassium sulfate }(52 \mathrm{~g} / \mathrm{kg}) \text {, magnesium oxide }(24 \mathrm{~g} / \mathrm{kg}) \text {, magnesium } \\
\text { oxide }(24 \mathrm{~g} / \mathrm{kg}) \text {, manganous carbonate }(3.5 \mathrm{~g} / \mathrm{kg}) \text {, ferric citrate }(6 \\
\mathrm{g} / \mathrm{kg}), \text { zinc carbonate }(1.6 \mathrm{~g} / \mathrm{kg}) \text {, cupric carbonate }(0.3 \mathrm{~g} / \mathrm{kg}) \text {, potassium } \\
\text { iodate }(0.01 \mathrm{~g} / \mathrm{kg}) \text {, sodium selenite }(0.01 \mathrm{~g} / \mathrm{kg}) \text {, chromium potassium } \\
\text { sulfate }(0.55 \mathrm{~g} / \mathrm{kg}) \text {. } \\
{ }^{2)} \mathrm{Vitamine} \mathrm{mix} ; \text { sucrose }(981.15 \mathrm{~g} / \mathrm{kg}) \text {, thiamine }(0.6 \mathrm{~g} / \mathrm{kg}) \text {, vitamin } \mathrm{E} \\
\text { acetate }(500 \mathrm{IU} / \mathrm{g} ; 10 \mathrm{~g} / \mathrm{kg}), \text { niacin }(3 \mathrm{~g} / \mathrm{kg}) \text {, calcium pantothenate }(1.6 \\
\mathrm{g} / \mathrm{kg}) \text {, vitamin B12 }(0.1 \% ; 1 \mathrm{~g} / \mathrm{kg}) \text {, vitamin A palmitate }(500,000 \mathrm{IU} / \mathrm{g} \text {; } \\
0.8 \mathrm{~g} / \mathrm{kg}), \mathrm{pyridoxine}(0.7 \mathrm{~g} / \mathrm{kg}) \text {, riboflavin }(0.6 \mathrm{~g} / \mathrm{kg}) \text {, vitamin D } 3 \\
\text { (400,000 IU } / \mathrm{g} ; 0.25 \mathrm{~g} / \mathrm{kg}) \text {, folic acid }(0.2 \mathrm{~g} / \mathrm{kg}) \text {, menadione sodium } \\
\text { bisulfate }(0.08 \mathrm{~g} / \mathrm{kg}), \text { biotin }(0.02 \mathrm{~g} / \mathrm{kg}) \text {. } \\
\text { 3) } \mathrm{TBHQ} \text { tert-butylhydroquinone. }\end{array}$} \\
\hline
\end{tabular}

Table 1. Composition of diets

matrix-assisted laser desorption/ionization-time-of-flight (MALDI-TOF) analysis (Ettan MALDI-TOF Pro, GE Healthcare). Spectra were collected from 350 shots per spectrum over an $m / z$ range of $600-3000$ and calibrated by two point internal calibration using trypsin auto-digestion peaks ( $\mathrm{m} / \mathrm{z} 842.5099,2211.1046)$. Peak list was generated using the Ettan MALDI-TOF Pro Evaluation Module (ver 2.0.16). The threshold used for peak-picking was as follows: 5,000 for minimum resolution of monoisotopic mass, 2.5 for S/N. The search program MASCOT (Mascot Sever 2.3), developed by Matrixscience (http://www.matrixscience. com), was used for protein identification by PMF. The following parameters were used for the database search: trypsin as the cleaving enzyme, a maximum of one missed cleavage, iodoacetamide (Cys) as a fixed modification, oxidation (Met) as a variable modification, monoisotopic masses, and a mass tolerance of \pm 0.1 Da. MASCOT probability-based MOWSE (molecular weight search) score was calculated for PMF. Protein score is $-10 * \log (\mathrm{P})$, where $\mathrm{P}$ is the probability that the observed match is a random event, and greater than 61 is considered to be significant $(p<0.05)$.

\section{Cell culture}

Chang cells (originated from human liver, ATCC) were cultured in Minimum essential medium (Eagle) in Earle's BSS containing non-essential amino acids, $1 \mathrm{mM}$ sodium pyruvate, $10 \mathrm{mM}$ HEPES, $2 \mathrm{mM} \mathrm{L-}$ glutamine, $50 \mathrm{U} / \mathrm{ml}$ of penicillin, $50 \mathrm{~g} / \mathrm{ml}$ of streptomycin, and $10 \%$ heat-inactivated fetal bovine serum (FBS) in a $37^{\circ} \mathrm{C}$-humidified $5 \% \mathrm{CO}_{2}$ incubator. All reagents for cell culture were purchased from Invitrogen (Grand island, NY, USA). 


\begin{tabular}{ll|l}
$\begin{array}{c}\text { Cellular Physiology } \\
\text { and Biochemistry }\end{array}$ & Cell Physiol Biochem 2012;30:295-306 \\
\cline { 2 - 3 } & $\begin{array}{l}\text { DOI: 10.1159/000339065 } \\
\text { Published online: June 22, 2012 }\end{array}$ & $\begin{array}{l}\text { O 2012 S. Karger AG, Basel } \\
\text { www.karger.com/cpb }\end{array}$ \\
\cline { 2 - 3 } & Choi/Liu/Mukherjee/Yun: Ft-B and ZAG in Fatty Acid Metabolism
\end{tabular}

\begin{tabular}{|c|c|c|}
\hline Genes & & Primer sequence $\left(5^{\prime}-3^{\prime}\right)$ \\
\hline \multirow{2}{*}{ FETUB } & $\mathrm{F}^{a}$ & СССТCAACCCCTCGGCTCTGCTCTC \\
\hline & $\mathrm{R}^{b}$ & CCGTCTGTATTCCTGGGCGTCGTTCACTC \\
\hline \multirow{2}{*}{$A Z G P 1$} & $\mathrm{~F}$ & AGGTGCAGGAGCCTGAGTTA \\
\hline & $\mathrm{R}$ & CAACCCTTGCTTCCTAGCTG \\
\hline \multirow{2}{*}{$A C C 1$} & $\mathrm{~F}$ & ACCACCAATGCCAAAGTAGC \\
\hline & $\mathrm{R}$ & CTGCAGGTTCTCAATGCAAA \\
\hline \multirow{2}{*}{$F A S N$} & $\mathrm{~F}$ & CTGGCTCAGCACCTCTATCC \\
\hline & $\mathrm{R}$ & CAGGTTGTCCCTGTGATCCT \\
\hline \multirow{2}{*}{$M E 1$} & $\mathrm{~F}$ & GGATTGCACACCTGATTGTG \\
\hline & $\mathrm{R}$ & TCTTCATGTTCATGGGCAAA \\
\hline \multirow{2}{*}{$M E 2$} & $\mathrm{~F}$ & ATGGGCTTGTACCAGAAACG \\
\hline & $\mathrm{R}$ & TGCTGCAAGAAGACCTGCTA \\
\hline \multirow{2}{*}{$M E 3$} & $\mathrm{~F}$ & CAGCAGAGTGACCTGGACAA \\
\hline & $\mathrm{R}$ & GTCAGGCCATAGTGCTGACA \\
\hline \multirow{2}{*}{$P R K A A 2$} & $\mathrm{~F}$ & CACATCCATTTGGCATGAAG \\
\hline & $\mathrm{R}$ & GGCAAAAATGCTTTCTCTGG \\
\hline \multirow{2}{*}{$P R K A B 1$} & $\mathrm{~F}$ & TCCGATGTGTCTGAGCTGTC \\
\hline & $\mathrm{R}$ & GTTCAGCATGACGTGATTGG \\
\hline \multirow{2}{*}{$A C C 2$} & $\mathrm{~F}$ & GCAGCTGATGACCAACTTCA \\
\hline & $\mathrm{R}$ & CAGCTTCACCTGTGGTCAGA \\
\hline \multirow{2}{*}{$C P T 1 B$} & $\mathrm{~F}$ & TAAGAAGCACCAGAATATGTACCGC \\
\hline & $\mathrm{R}$ & GTACTTGGAGACCAAGTAAAGGCAG \\
\hline \multicolumn{3}{|c|}{ Internal control } \\
\hline \multirow{2}{*}{ GAPDH } & $\mathrm{F}$ & GTCATCCATGACAACTTTGG \\
\hline & $\mathrm{R}$ & ССACСТTCTTGATGTCATC \\
\hline
\end{tabular}

Table 2. Sequences of the primers used for real-time RT-PCRs.

\section{Transient knockdown of AZGP1 and FETUB}

To knockdown AZGP1 and FETUB, commercial siRNAs (Santa Cruz Biotechnology, Santa Cruz, CA, USA), which are pools of three target-specific 20-25 nt siRNAs designed to KD gene expression, were used. Chang cells $\left(2 \times 10^{5}\right.$ cells/well in a 6-well plate) were transiently transfected with siRNA ( 80 pmol per well) and agent ( $6 \mu \mathrm{l}$ per well) using siRNA Transfection Reagent (Santa Cruz Biotechnology), and gene expression levels were examined in cells cultured after $48 \mathrm{~h}$. Transfection efficiency was monitored by estimating the uptake of non-targeting fluorescein-labeled double-stranded RNA oligomers (BLOCK-iT, $150 \mathrm{nM}$ per well, \#2013, Invitrogen). Transcript level of each gene was normalized to GAPDH transcript levels. Finally, KD efficiency of transiently siRNA-expressing cells was determined as follows:

$\%$ Gene expression $=(\mathrm{a}-\mathrm{b}) / \mathrm{b} \times 100$

a: Normalized expression level of each gene in siRNA-transfected cells

b: Normalized expression level of each gene in BLOCK-iT-transfected cells

\section{Quantitative real-time RT-PCR}

Transcript levels of genes were quantitatively determined by real-time RT-PCR (Stratagene $246 \mathrm{mx}$ $3000 p$ QPCR System). Total RNA was isolated from cells using an easy-spin ${ }^{\mathrm{TM}}$ (DNA-free) Total RNA Extraction kit (iNtRON Biotechnology, Seongnam, Korea), and reverse-transcription was carried out using a Maxime RT Premix kit (iNtRON Biotechnology). We employed the SYBR Green Dye system (Applied Biosystems, Foster City, CA, USA) for real-time PCR. Sequences of primer sets are listed in Table 2.

\section{Immunoblotting analysis}

Cell lysates were prepared with RIPA buffer (Sigma), homogenized, and centrifuged at 12,000 $\times g$ for 20 min. Extract of cells was diluted in sample buffer (50 mM Tris of pH 6.8), 2\% SDS, 10\% glycerol, $0.1 \%$ bromophenol blue, and $5 \% \beta$-mercaptoethanol) and heated for 5 min before SDS-polyacrylamide gel electrophoresis (PAGE) gel at 6, 8, 10, or 12\%. After electrophoresis, proteins were transferred to a polyvinylidene difluoride (Santa Cruz Biotechnology) membrane and blocked for $1 \mathrm{~h}$ with TBS (tris- 


\section{Cellular Physiology $\quad$ Cell Physiol Biochem 2012;30:295-306

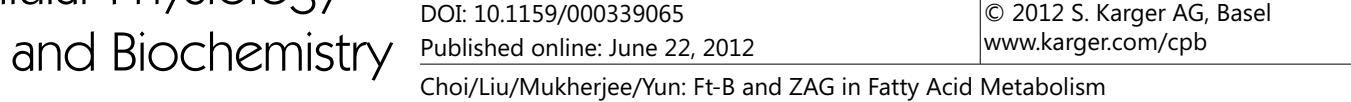

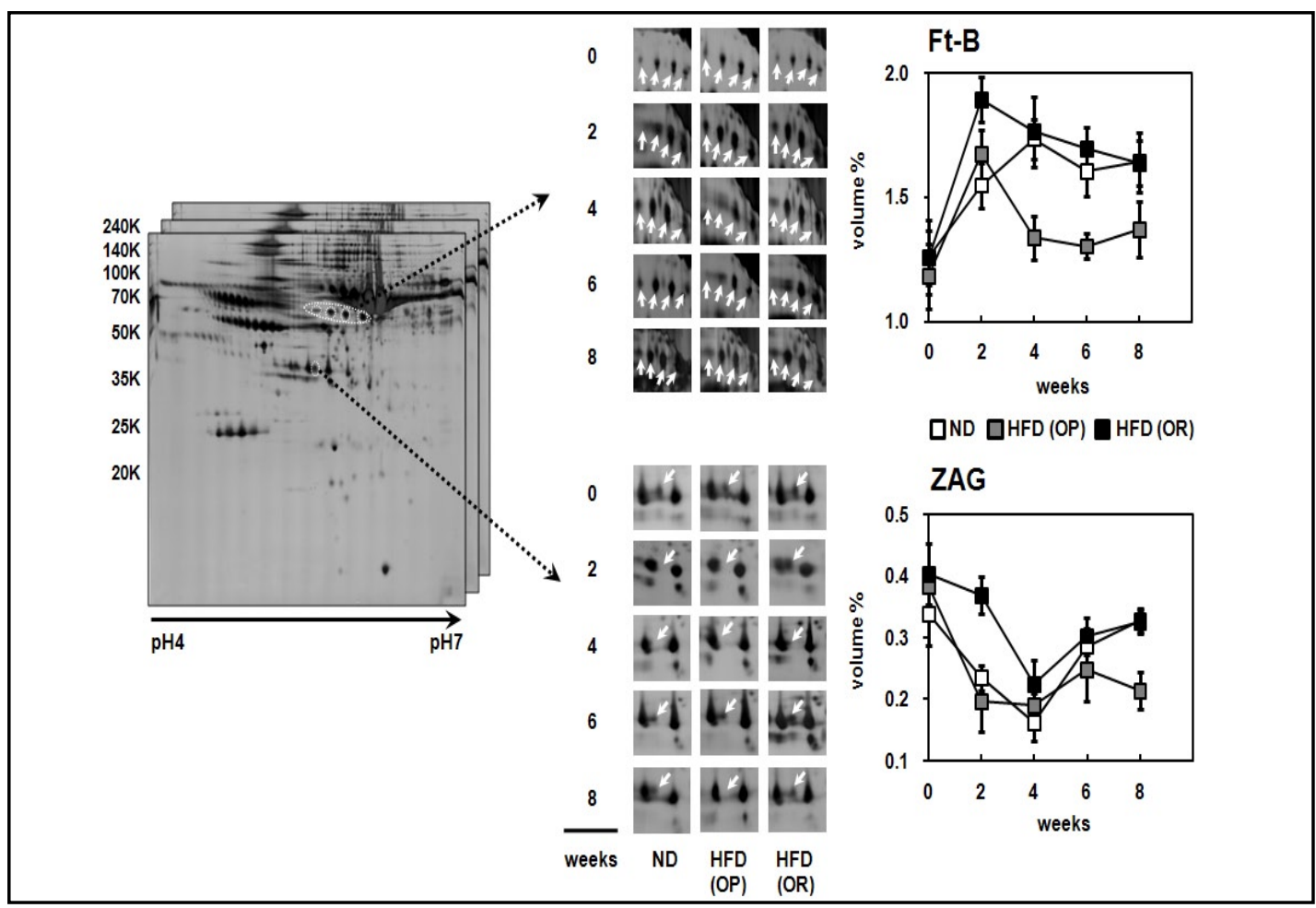

Fig. 2. Time-dependent differential regulation of Ft-B and ZAG between obesity-prone (OP) and obesityresistant (OR) rat plasma. Data are displayed as mean values \pm SD of volume density (\%) of the changed spot in three individual gels using pooled plasma from seven rats per group.

buffered saline)-T buffer (10 mM Tris- $\mathrm{HCl}, 150 \mathrm{mM} \mathrm{NaCl}, 0.1 \%$ Tween 20 containing 5\% skim milk). The membrane was rinsed with three changes of TBS-T buffer, followed by incubation for $1 \mathrm{~h}$ with a 1:1000 dilution of primary polyclonal antibody (anti- $\beta$-actin, Ft-B, ZAG, FAS, pAMPK, pACC, and CPT1; Santa Cruz Biotechnology) in TBS-T buffer containing 1\% skim milk. After three washes, the membrane was incubated for $1 \mathrm{~h}$ with horseradish peroxidase-conjugated anti-mouse IgG or anti-goat IgG (1:1000, Santa Cruz Biotechnology) in TBS-T buffer containing 1\% skim milk and developed by enhanced chemiluminescence (ECL; GE healthcare). Immunoblot analysis was performed by scanning using a UMAX PowerLook 1120 and digitalized using image analysis software (KODAK 1D, Eastman Kodak, Rochester, NY, USA).

\section{Oil Red-O Staining}

At room temperature, cells were washed with PBS, fixed with $10 \%$ formalin (DC Chemical Co., Ltd, Seoul, Korea) for $1 \mathrm{~h}$, and washed for $5 \mathrm{~min}$ each with deionized water and 60\% isopropanol (DC Chemical Co., Ltd). Completely dried cells were stained with Oil Red-0 solution (six parts $0.6 \%$ Oil Red-O dye (Sigma) in isopropanol and four parts water) for $1 \mathrm{~h}$, washed four times with deionized water, and then stained cell images were acquired under the microscope for analysis.

\section{TG content assay}

Cells were washed twice with PBS, scraped, and harvested. Cell lysates were prepared with RIPA buffer (Sigma) by incubation for $30 \mathrm{~min}$ at $4{ }^{\circ} \mathrm{C}$. TG content in the cells was measured using a TG test kit (Asan pharm. Co. Yeongcheon, Kyungbuk, Korea) according to the manufacturer's instructions. Absorbance was measured at $550 \mathrm{~nm}$, and TG content was normalized to the protein content by the Bradford method [27] using protein assay dye reagent concentrate (Bio-Rad).

\section{Statistical analysis}

All data expressed as the mean \pm SD were compared by one-way analysis of variance (ANOVA) using the Statistical Package of Social Science (SPSS, version 14.0K) program. Group means were considered significantly different at $p<0.05$, as determined by the technique of protected least-significant difference (LSD) when ANOVA indicated an overall significant treatment effect $(p<0.05)$. 


\begin{tabular}{|c|c|c|}
\hline $\mathrm{Col}$ & Cell Physiol Biochem 2012;30:295-306 & \\
\hline and Biochemistry & $\begin{array}{l}\text { DOI: } 10.1159 / 000339065 \\
\text { Published online: June 22, } 2012\end{array}$ & $\begin{array}{l}\text { O) } 2012 \text { S. Karger AG, Basel } \\
\text { www.karger.com/cpb }\end{array}$ \\
\hline
\end{tabular}

Fig. 3. Effects of FETUB and AZGP1 KD on expression levels of genes involved in lipogenesis (white bars) and $\beta$-oxidation (black bars) in liver cells. Transcript levels of each gene were normalized to GAPDH transcript levels. Data are displayed as mean values \pm SD of $\% \mathrm{KD}$. Data are representative of three independent assays. Statistical significance between each group was determined by ANOVA test, where $p$ value is ${ }^{*} p<0.05$ and ${ }^{* *} p<0.01$.

\section{Results}

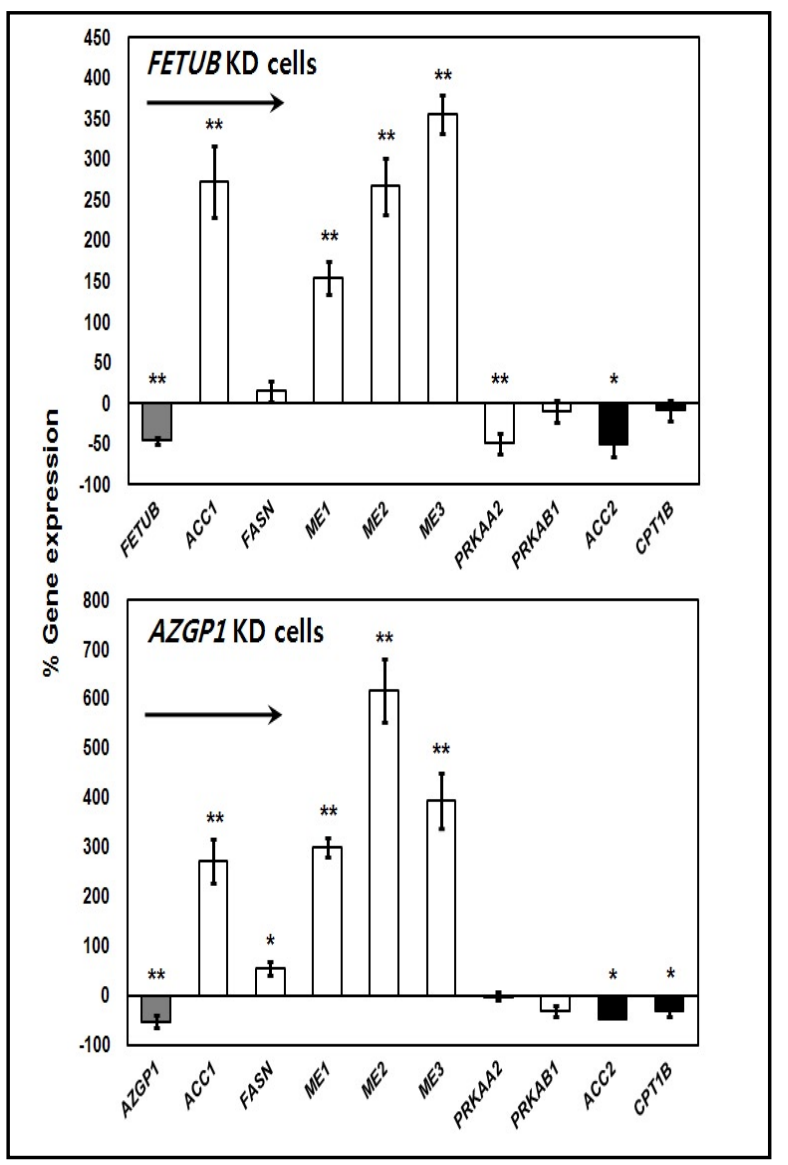

Time-dependent proteome profiling focusing on Ft-B and ZAG

To determine whether or not the protein levels of Ft-B and ZAG are stably regulated during the entire rat breeding period, we conducted time-dependent plasma proteome profiling focusing on the two proteins. As shown in Fig. 2, both Ft-B and ZAG in OR rats were at higher levels than in OP rats throughout the entire period, thus encouraging us to further study the functional roles of these proteins in obesity.

Effects of FETUB and AZGP1 KD on expression of genes involved in fatty acid metabolism

To directly test the physiological significance of Ft-B and ZAG, we decided to specifically knock down FETUB and AZGP1 encoding Ft-B and ZAG, respectively, in human liver cells by using siRNA. To construct FETUB and AZGP1 KD cells, commercial siRNAs (pools of three target-specific 20-25 nt siRNAs) were used to transiently transfect human-derived Chang liver cells. Next, we examined transcriptional changes in genes related to fatty acid metabolism, including ME (ME1, ME2, and ME3), PRKAA2, PRKAB1, ACC (ACC1 and ACC2), $F A S N$, and $C P T 1 B$, in FETUB KD and AZGP1 KD cells in comparison with control cells. Results of real-time RT-PCRs revealed similar altered gene expression patterns between FETUB KD and AZGP1 KD cells (Fig. 3). Transcript levels of genes encoding malic enzymes (ME1, ME2, and ME3) as well as ACC1 and FASN were significantly higher in both KD cells in comparison with control cells transfected with non-targeting fluorescein-labeled dsRNA oligomers. In contrast, the expression levels of $A C C 2$, PRKAA2, and CPT1B were lower in both KD cells (Fig. $3)$.

Effects of FETUB and AZGP1 KD on lipogenesis in liver cells

We further confirmed the effects of FETUB and AZGP1 KD on the protein production of Ft-B and ZAG in liver cells. As shown in Fig. 4A, Ft-B and ZAG protein expression levels in 


\begin{tabular}{|c|c|c|}
\hline \multirow{2}{*}{$\begin{array}{c}\text { Cellular Physiolosy } \\
\text { and Biochemistry }\end{array}$} & \multirow{2}{*}{\multicolumn{2}{|c|}{$\begin{array}{l}\text { Cell Physiol Biochem 2012;30:295-306 } \\
\text { DOI } 10.1159 / 000339065\end{array}$}} \\
\hline & & $\begin{array}{l}\text { (c) } 2012 \text { S. Karger AG, Base } \\
\text { www.karger.com/cpb }\end{array}$ \\
\hline
\end{tabular}

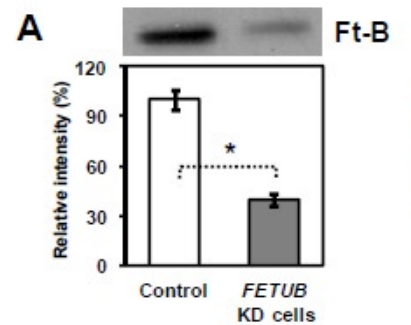

B

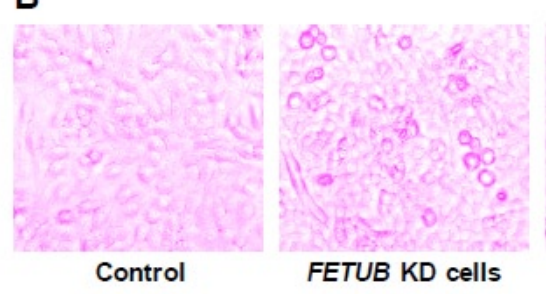

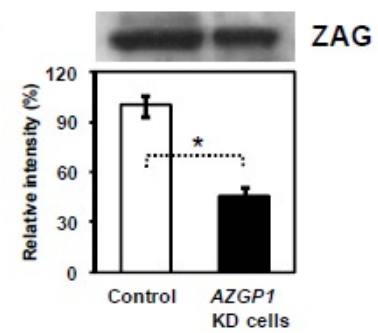

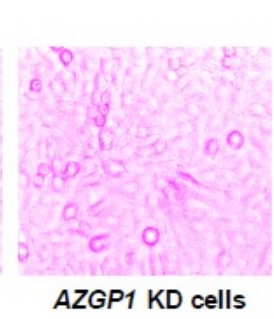

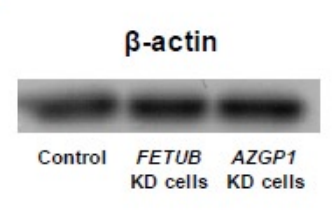

C

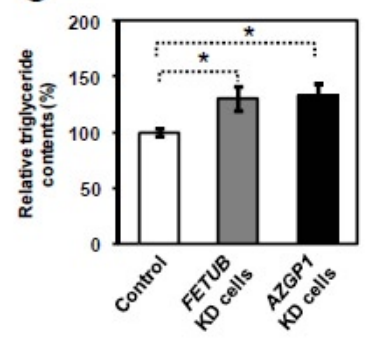

Fig. 4. Effects of FETUB and AZGP1 KD on fatty acid synthesis in liver cells. (A) Ft-B and ZAG protein expression levels after KD using siRNA, (B) Oil Red-O staining, (C) TG content assay. Band density was calculated using ImageMaster 2D software version 4.95, and relative intensity (\%) demonstrated that protein levels were normalized to those of $\beta$-actin. Data are shown representative of three experiments. ${ }^{*} p<0.05$.

Fig. 5. Effects of FETUB and $A Z G P 1$ KD on expression levels of some selected proteins involved in fatty acid metabolism in liver cells as measured by immunoblot analysis. Band density was calculated using ImageMaster 2D software version 4.95, and relative intensity (\%) demonstrated that protein levels were normalized to those of $\beta$-actin. Data are shown representative of three independent experiments. ${ }^{*} p<0.05$ and ${ }^{* *} p<0.01$.

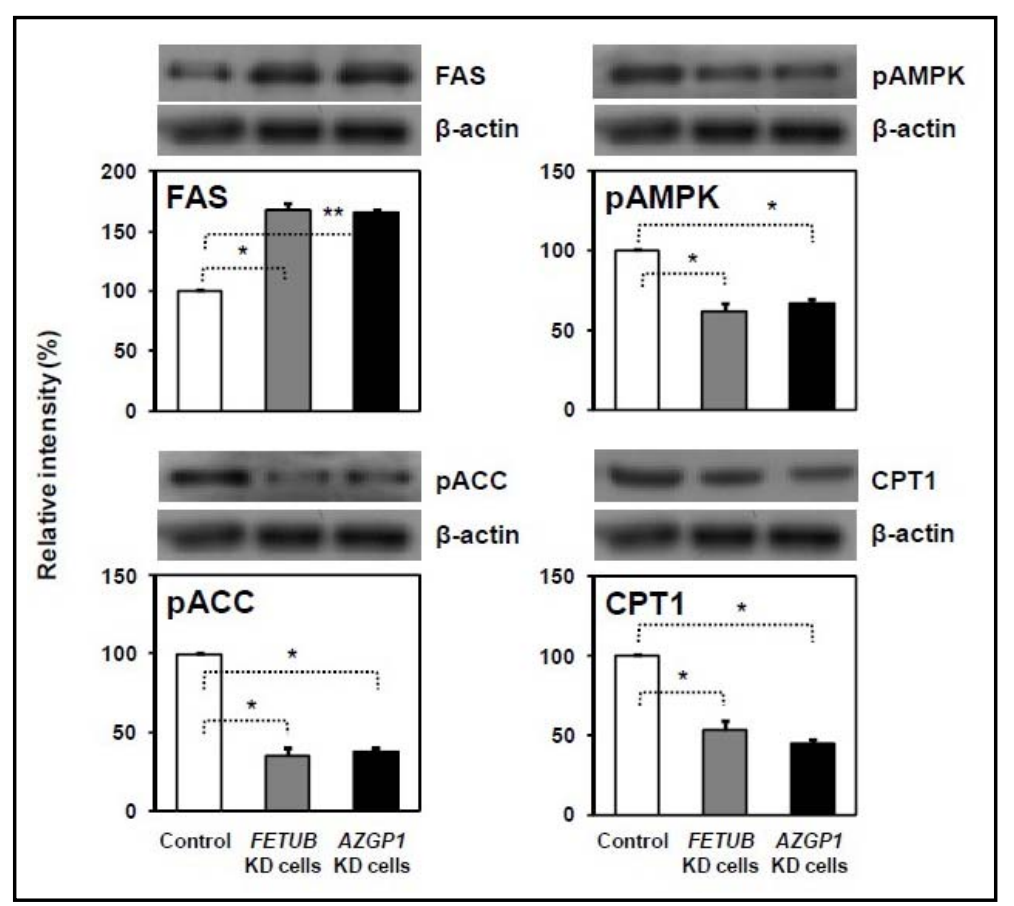

FETUB and AZGP1 KD cells were markedly reduced by averages of approximately $60 \%$ and $55 \%$, respectively, compared to those in control cells. Next, we determined intracellular lipid droplet formation and TG content in both KD cells by Oil Red-O staining and TG content assay, respectively. Expectedly, lipid droplet formation and cellular TG content were significantly higher in both KD cells (Fig. 4B, C).

Effects of FETUB KD and AZGP1 KD on regulation of fatty acid metabolism-related proteins in liver cells

We further measured the levels of several proteins in liver cells by Western blot analysis before and after KD to test whether or not differential expression patterns of the 


\section{Cellular Physiology and Biochemistry}

Cell Physiol Biochem 2012;30:295-306

\begin{tabular}{l|l}
\hline DOI: 10.1159/000339065 & $\begin{array}{l}\text { C) 2012 S. Karger AG, Basel } \\
\text { www.karger.com/cpb }\end{array}$ \\
Published online: June 22, 2012 &
\end{tabular}

genes ultimately affect protein levels. To this end, we determined the altered protein levels of FAS, pACC, and pAMPK in both types of KD cells. In both KD cells, protein levels of pACC and pAMPK decreased, whereas levels of FAS increased, in comparison with control cells, suggesting a higher rate of fatty acid synthesis via the ACC pathway (Fig. 5). Accordingly, in both KD cells, the level of CPT1, the key enzyme involved in mitochondrial $\beta$-oxidation, decreased.

\section{Discussion}

Most proteomic studies use biofluids and biopsies obtained not at various time points but at a single time point. These approaches typically yield conflicting results, in that many investigators have reported different regulation patterns for the same proteins in disease states. Therefore, determination of biomarker proteins for the prognosis and diagnosis of diseases along with time profiling of candidate proteins are strongly recommended [29, 30].

In the current study, we performed time-dependent plasma proteome analysis in lean and obese rats fed a HFD (OP and OR rats). Among the numerous plasma proteins showing differential regulation between OP and OR rats, Ft-B and ZAG were stably regulated during the entire breeding period, but lower plasma protein levels of both were observed in OP rats compared to $\mathrm{OR}$ rats. These results imply the possibility of using these proteins as plasma markers of diet-induced obesity. Next, we attempted to knock down the genes encoding Ft$B$ and ZAG in liver cells, and we also investigated the expression levels of genes associated with fatty acid metabolism. To this end, we applied the RNAi methodology to human tissuederived cell lines in order to circumvent the technical obstacles associated with knockout animals as well as to dissect the molecular mechanisms of gene KD without having a drastic effect on global cell functions accompanied by a broad range of indirect phenotypes [31]. Our KD cells exhibited significantly increased expression of genes involved in fatty acid synthesis $(M E, A C C 1$, and $F A S N)$ as well as decreased expression of the key gene in fat $\beta$-oxidation $(C P T 1 B)$.

Malic enzymes (ME), which convert pyruvate to malate, play roles in lipogenesis by furnishing NADPH for the reduction of acetyl CoA to fatty acids [32]. Specifically, it has been suggested that alterations in the activity of MEs accompany changes in the dietary regime [32]. Based on previous information, the significant increase in the expression levels of ME in both KD cells is likely associated with operation of the Krebs cycle and eventually export of intra-mitochondrial acetyl CoA into the cytoplasm in the form of citrate for the facilitation of fatty acid synthesis [33].

Acetyl-CoA carboxylase (ACC) 1 and ACC2, which are the two main isoforms of ACC, show differences in tissue distribution and function in mammals. Whereas ACC1 is enriched in lipogenic tissues such as liver and adipose tissues [34], ACC2 is expressed in oxidative tissues such as skeletal muscle, heart, and liver [35]. The differences in tissue distribution between the two ACC isoforms suggest that ACC1 is involved in regulation of fatty acid synthesis, whereas ACC2 mainly regulates fatty acid oxidation [36]. Along this same line, we observed significantly increased ACC1 and decreased ACC2 expression in both FETUB KD and $A Z G P 1$ KD liver cells (Fig. 3). Consequently, expression of fatty acid synthase gene (FASN) was also reduced in both KD cells, albeit to a lesser extent than ACC. Taken together, these results provide a possibility of impaired fatty acid oxidation during the development of dietinduced obesity in OP rats, but not OR rats fed a HFD.

The most remarkable outcome of this study is the novel finding that higher protein levels of Ft-B were observed throughout the entire period of obesity development in rats fed a HFD. Ft-A, the first member of the fetuin family, is well known to be associated with diabetes, obesity, and other metabolic diseases [37-39]. There is now a consensus that higher circulating protein levels of Ft-A are associated with increased insulin resistance $[10-14,40,41]$ and fatty liver diseases $[10,42]$. Nonetheless, some studies also revealed no association between blood protein levels of Ft-A with insulin sensitivity or resistance 


\section{Cellular Physiology Cell Physiol Biochem 2012;30:295-306

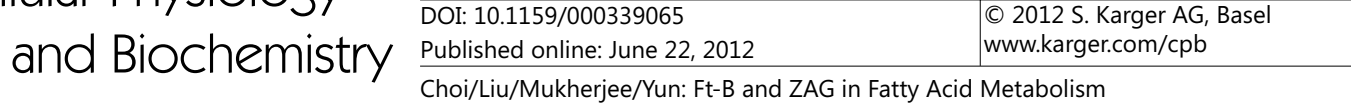

[15] or reduced levels in patients with type 2 diabetes [16,17]. Most of the earlier studies were cross-sectional by simply comparing the blood protein levels between healthy subjects and patients, and thus susceptible to many confounders. In this regard, functional studies as established in this study are preferable to clarify physiological role of Ft-A.

In our previous two independent proteomic studies, we found lower plasma protein levels of Ft-A and Ft-B in obese rats fed a HFD $[1,5]$. Our proteomic data are not compatible with the results of many earlier clinical studies as mentioned above. However, we claim that increased regulation of Ft-A in the liver may be a reason for overcoming fat toxicity in OR rats, which may be similar case to Ft-B. Our data from KD study support this hypothesis, in that lipogenesis was accelerated in Ft-B deficient hepatocytes (Figs. 3, 4, 5). Nonetheless, it is noteworthy that we do not have proof that result of FETUA KD exhibits increased lipogenesis similar with FETUB KD.

In this study, we also observed higher plasma protein levels of ZAG, which has been reported to be associated with obesity as a lipid-mobilizing factor in various studies [43-45]. ZAG leads to phosphorylation of AMPK $\alpha$ and ACC, thereby activating a pathway central to the regulation of energy metabolism in human primary skeletal muscle cells [46]. Moreover, the action of ZAG is correlated with decreased FAS expression as well as increased hormonesensitive lipase (HSL) expression in both adipose and liver tissues in obese mice [22, 47]. The current study showed for the first time that $A Z G P 1 \mathrm{KD}$ in liver cells promoted lipogenesis by increasing the expression of genes encoding lipogenic enzymes as well as decreasing the expression of genes encoding $\beta$-oxidation enzymes (Fig. 3).

The results of the Western blot analysis also support these data, in that inhibition of the phosphorylation of ACC and AMPK promoted lipogenesis. Taken together, we can conclude that $A Z G P 1 \mathrm{KD}$ and FETUB KD resulted in significantly higher expression of lipogenic target genes. As another consequence of AZGP1 KD and FETUB KD, lower concentrations of pAMPK and pACC facilitated higher TG synthesis as well as lower CPT1-driven fat oxidation (Figs. 4, 5).

In conclusion, our results provide a possible relationship between reduced plasma protein levels of Ft-B and ZAG and a higher risk of diet-induced obesity through impaired fatty acid metabolism.

\section{Abbreviations}

2-DE (two-dimensional electrophoresis); ACC (acetyl-CoA carboxylase); AMPK (AMPactivated protein kinase); AZGP1 (zinc- $\alpha 2$-glycoprotein-encoding gene); CPT (carnitine palmitoyl transferase); FAS (fatty acid synthase); FETUB (fetuin-B-encoding gene); FFA (free fatty acid); Ft (fetuin); HFD (high fat diet); KD (knockdown); ME (malic enzyme); ND (normal diet); OP (obesity-prone); OR (obesity-resistant); TG (triglyceride); ZAG (zinc- $\alpha 2$ glycoprotein).

\section{Acknowledgements}

This work was supported by the Mid-career Researcher Program (grant number 20120000416) and SRC program (Center for Food \& Nutritional Genomics:grant number 20120000638) of the National Research Foundation of Korea (NRF) funded by the Ministry of Education, Science and Technology. Jung-Won Choi, Hao Liu, and Rajib Mukherjee received the BK21 scholarship.

\section{References}

1 Choi JW, Wang X, Joo JI, Kim DH, Oh TS, Choi DK, Yun JW: Plasma proteome analysis in diet-induced obesityprone and obesity-resistant rats. Proteomics 2010;10:4386-4400. 


\section{Cellular Physiology Cell Physiol Biochem 2012;30:295-306 \\ \begin{tabular}{ll|l} 
and BiOChemistry & $\begin{array}{l}\text { DOI: 10.1159/000339065 } \\
\text { Published online: June 22, } 2012\end{array}$ & $\begin{array}{l}\text { C 2012 S. Karger AG, Basel } \\
\text { www.karger.com/cpb }\end{array}$ \\
\cline { 2 - 3 } & Choi/Liu/Mukherjee/Yun: Ft-B and ZAG in Fatty Acid Metabolism
\end{tabular}}

2 Kim DH, Choi JW, Joo JI, Wang X, Choi DK, Oh TS, Yun JW: Changes in expression of skeletal muscle proteins between obesity-prone and obesity-resistant rats induced by a high-fat diet. J Proteome Res 2011;10:12811292.

3 Joo JI, Oh TS, Kim DH, Choi DK, Wang X, Choi JW, Yun JW: Differential expression of adipose tissue proteins between obesity-susceptible and -resistant rats fed a high-fat diet. Proteomics 2011;11:1429-1448.

4 Wang X, Choi JW, Joo JI, Kim DH, Oh TS, Choi DK, Yun JW: Differential expression of liver proteins between obesity-prone and obesity-resistant rats in response to a high-fat diet. Br J Nutr 2011;106:612-626.

5 Choi JW, Liu H, Choi DK, Oh TS, Mukherjee R, Yun JW: Profiling of gender-specific rat plasma proteins associated with susceptibility or resistance to diet-induced obesity. J Proteomics 2012;75:1386-1400.

6 Olivier E, Soury E, Ruminy P, Husson A, Parmentier F, Daveau M, Salier JP: Fetuin-B, a second member of the fetuin family in mammals. Biochem J 2000;350 Pt 2:589-597.

7 Denecke B, Graber S, Schafer C, Heiss A, Woltje M, Jahnen-Dechent W: Tissue distribution and activity testing suggest a similar but not identical function of fetuin-B and fetuin-A. Biochem J 2003;376:135-145.

8 Pedersen KO: Ultracentrifugal and electrophoretic studies on fetuin. J Phys Colloid Chem 1947;51:164-171.

9 Mathews ST, Singh GP, Ranalletta M, Cintron VJ, Qiang X, Goustin AS, Jen KL, Charron MJ, Jahnen-Dechent W, Grunberger G: Improved insulin sensitivity and resistance to weight gain in mice null for the ahsg gene. Diabetes 2002; 51:2450-2458.

10 Reinehr T, Roth CL: Fetuin-A and its relation to metabolic syndrome and fatty liver disease in obese children before and after weight loss. J Clin Endocrinol Metab 2008;93:4479-4485.

11 Ix JH, Shlipak MG, Brandenburg VM, Ali S, Ketteler M, Whooley MA: Association between human fetuin-A and the metabolic syndrome: Data from the heart and soul study. Circulation 2006;113:1760-1767.

12 Fiore CE, Celotta G, Politi GG, Di Pino L, Castelli Z, Mangiafico RA, Signorelli SS, Pennisi P: Association of high alpha2-heremans-schmid glycoprotein/fetuin concentration in serum and intima-media thickness in patients with atherosclerotic vascular disease and low bone mass. Atherosclerosis 2007;195:110-115.

13 Weikert C, Stefan N, Schulze MB, Pischon T, Berger K, Joost HG, Haring HU, Boeing H, Fritsche A: Plasma fetuin-A levels and the risk of myocardial infarction and ischemic stroke. Circulation 2008;118:2555-2562.

14 Ix JH, Wassel CL, Kanaya AM, Vittinghoff E, Johnson KC, Koster A, Cauley JA, Harris TB, Cummings SR, Shlipak MG: Fetuin-A and incident diabetes mellitus in older persons. JAMA 2008;300:182-188.

15 Mori K, Emoto M, Yokoyama H, Araki T, Teramura M, Koyama H, Shoji T, Inaba M, Nishizawa Y: Association of serum fetuin-A with insulin resistance in type 2 diabetic and nondiabetic subjects. Diabetes Care 2006;29:468.

16 Gunduz FO, Yildirmak ST, Temizel M, Faki Y, Cakmak M, Durmuscan M, Sezgin F: Serum visfatin and fetuin-A levels and glycemic control in patients with obese type 2 diabetes mellitus. Diabetes Metab J 2011;35:523528.

17 Yilmaz MI, Saglam M, Qureshi AR, Carrero JJ, Caglar K, Eyileten T, Sonmez A, Cakir E, Oguz Y, Vural A, Yenicesu M, Stenvinkel P, Lindholm B, Axelsson J: Endothelial dysfunction in type-2 diabetics with early diabetic nephropathy is associated with low circulating adiponectin. Nephrol Dial Transplant 2008;23:1621-1627.

18 Tada T, Ohkubo I, Niwa M, Sasaki M, Tateyama H, Eimoto T: Immunohistochemical localization of zn-alpha 2-glycoprotein in normal human tissues. J Histochem Cytochem 1991;39:1221-1226.

19 Bing C, Bao Y, Jenkins J, Sanders P, Manieri M, Cinti S, Tisdale MJ, Trayhurn P: Zinc-alpha2-glycoprotein, a lipid mobilizing factor, is expressed in adipocytes and is up-regulated in mice with cancer cachexia. Proc Natl Acad Sci U S A 2004;101:2500-2505.

20 Dahlman I, Kaaman M, Olsson T, Tan GD, Bickerton AS, Wahlen K, Andersson J, Nordstrom EA, Blomqvist L, Sjogren A, Forsgren M, Attersand A, Arner P: A unique role of monocyte chemoattractant protein 1 among chemokines in adipose tissue of obese subjects. J Clin Endocrinol Metab 2005;90:5834-5840.

21 Mracek T, Ding Q Tzanavari T, Kos K, Pinkney J, Wilding J, Trayhurn P, Bing C: The adipokine zinc-alpha2glycoprotein (zag) is downregulated with fat mass expansion in obesity. Clin Endocrinol (Oxf) 2010;72:334341.

22 Gong FY, Zhang SJ, Deng JY, Zhu HJ, Pan H, Li NS, Shi YF: Zinc-alpha2-glycoprotein is involved in regulation of body weight through inhibition of lipogenic enzymes in adipose tissue. Int J Obes (Lond) 2009;33:10231030.

23 Russell ST, Tisdale MJ: Studies on the anti-obesity activity of zinc-alpha2-glycoprotein in the rat. Int J Obes (Lond) 2011;35:658-665.

24 Russell ST, Tisdale MJ: Studies on the antiobesity effect of zinc-alpha2-glycoprotein in the ob/ob mouse. Int J Obes (Lond) 2011;35:345-354. 


\section{Cellular Physiology Cell Physiol Biochem 2012;30:295-306 \\ \begin{tabular}{ll|l} 
and BiOChemistry & $\begin{array}{l}\text { DOI: 10.1159/000339065 } \\
\text { Published online: June 22, } 2012\end{array}$ & $\begin{array}{l}\text { (c) 2012 S. Karger AG, Basel } \\
\text { www.karger.com/cpb }\end{array}$ \\
\cline { 2 - 3 } & Choi/Liu/Mukherjee/Yun: Ft-B and ZAG in Fatty Acid Metabolism
\end{tabular}}

25 Rolli V, Radosavljevic M, Astier V, Macquin C, Castan-Laurell I, Visentin V, Guigne C, Carpene C, Valet P, Gilfillan S, Bahram S: Lipolysis is altered in mhc class i zinc-alpha(2)-glycoprotein deficient mice. FEBS Lett 2007;581:394-400.

26 Selva DM, Lecube A, Hernandez C, Baena JA, Fort JM, Simo R: Lower zinc-alpha2-glycoprotein production by adipose tissue and liver in obese patients unrelated to insulin resistance. J Clin Endocrinol Metab 2009;94:4499-4507.

27 Bradford MM: A rapid and sensitive method for the quantitation of microgram quantities of protein utilizing the principle of protein-dye binding. Anal Biochem 1976;72:248-254.

28 Choi JW, Hwang HS, Kim DH, Joo JI, Yun JW: Proteomic analysis of liver proteins in rats fed with a high-fat diet in response to capsaicin treatments. Biotechnol Bioproc E 2010;15:534-544.

29 Kim SW, Hwang HJ, Cho EJ, Oh JY, Baek YM, Choi JW, Yun JW: Time-dependent plasma protein changes in streptozotocin-induced diabetic rats before and after fungal polysaccharide treatments. J Proteome Res 2006;5:2966-2976.

30 Oh TS, Kwon EY, Choi JW, Choi MS, Yun JW: Time-dependent hepatic proteome analysis in lean and dietinduced obese mice. J Microbiol Biotechnol 2011;21:1211-1227.

31 Voorhoeve PM, Agami R: Knockdown stands up. Trends Biotechnol 2003;21:2-4.

32 Wise EM, Jr., Ball EG: Malic enzyme and lipogenesis. Proc Natl Acad Sci USA 1964;52:1255-1263.

33 Wada F, Maruyama E, Shibayama K, Sakamoto Y: Physiological role of malic enzymes in the liver. J Biochem 1968;63:805-807.

34 Kim TS, Leahy P, Freake HC: Promoter usage determines tissue specific responsiveness of the rat acetyl-coa carboxylase gene. Biochem Biophys Res Commun 1996;225:647-653.

35 Barber MC, Price NT, Travers MT: Structure and regulation of acetyl-coa carboxylase genes of metazoa. Biochim Biophys Acta 2005;1733:1-28.

36 Abu-Elheiga L, Brinkley WR, Zhong L, Chirala SS, Woldegiorgis G, Wakil SJ: The subcellular localization of acetyl-coa carboxylase 2. Proc Natl Acad Sci U S A 2000;97:1444-1449.

37 Takekoshi K, Fukuhara M, Quin Z, Nissato S, Isobe K, Kawakami Y, Ohmori H: Long-term exercise stimulates adenosine monophosphate-activated protein kinase activity and subunit expression in rat visceral adipose tissue and liver. Metabolism 2006;55:1122-1128.

38 Ix JH, Sharma K: Mechanisms linking obesity, chronic kidney disease, and fatty liver disease: The roles of fetuin-A, adiponectin, and ampk. J Am Soc Nephrol 2010;21:406-412.

39 Hennige AM, Staiger H, Wicke C, Machicao F, Fritsche A, Haring HU, Stefan N: Fetuin-A induces cytokine expression and suppresses adiponectin production. PLoS One 2008;3:e1765.

40 Jenkins NT, McKenzie JA, Hagberg JM, Witkowski S: Plasma fetuin-A concentrations in young and older highand low-active men. Metabolism 2011;60:265-271.

41 Xu Y, Xu M, Bi Y, Song A, Huang Y, Liu Y, Wu Y, Chen Y, Wang W, Li X, Ning G: Serum fetuin-A is correlated with metabolic syndrome in middle-aged and elderly chinese. Atherosclerosis 2011;216:180-186.

42 Stefan N, Hennige AM, Staiger H, Machann J, Schick F, Krober SM, Machicao F, Fritsche A, Haring HU: Alpha2heremans-schmid glycoprotein/fetuin-A is associated with insulin resistance and fat accumulation in the liver in humans. Diabetes Care 2006;29:853-857.

43 Marrades MP, Martinez JA, Moreno-Aliaga MJ: Zag, a lipid mobilizing adipokine, is downregulated in human obesity. J Physiol Biochem 2008;64:61-66.

44 Yeung DC, Lam KS, Wang Y, Tso AW, Xu A: Serum zinc-alpha2-glycoprotein correlates with adiposity, triglycerides, and the key components of the metabolic syndrome in chinese subjects. J Clin Endocrinol Metab 2009;94:2531-2536.

45 Russell ST, Zimmerman TP, Domin BA, Tisdale MJ: Induction of lipolysis in vitro and loss of body fat in vivo by zinc-alpha2-glycoprotein. Biochim Biophys Acta 2004;1636:59-68.

46 Eckardt K, Schober A, Platzbecker B, Mracek T, Bing C, Trayhurn P, Eckel J: The adipokine zinc-alpha2glycoprotein activates amp kinase in human primary skeletal muscle cells. Arch Physiol Biochem 2011;117:88-93.

47 Gong FY, Deng JY, Zhu HJ, Pan H, Wang LJ, Yang HB: Fatty acid synthase and hormone-sensitive lipase expression in liver are involved in zinc-alpha2-glycoprotein-induced body fat loss in obese mice. Chin Med Sci J 2010;25:169-175. 